\title{
History of Computing Education Trends: The Emergence of Competitive Intelligence
}

\author{
Kevin R. Parker ${ }^{1}$, Philip S. Nitse ${ }^{2}$, and Bill Davey ${ }^{3}$ \\ ${ }^{1}$ College of Business, Idaho State University, Pocatello USA: parkerkr@isu.edu \\ ${ }^{2}$ College of Business, Idaho State University, Pocatello USA; nitsphil@cob.isu.edu \\ ${ }^{3}$ School of Business Information Technology, RMIT University, Melbourne, Australia; \\ billd@rmit.edu.au
}

\begin{abstract}
Several studies have shown that new curriculum initiatives such as enterprise systems have a predictable lifecycle [1]. This paper looks for trends in competitive intelligence $(\mathrm{CI})$, a relatively new area of study that is beginning to infiltrate curricula around the world. We first examine existing research concerning CI and academia, listing the various approaches through which CI's role in educational curricula is considered and tracing the history of its emergence. A survey of CI course offerings throughout the US and Australia was conducted in an attempt to identify trends outside a single culture or education system. It shows that $\mathrm{CI}$ is an emerging discipline and often appears as an independent degree program rather than just a component of other programs. The methodology used in this study demonstrates how a historical perspective can be used to identify new issues to be considered by curriculum planners.
\end{abstract}

Keywords: Curriculum trends, Competitive intelligence, Computer education, Computing history

\section{Introduction}

The curriculum planner in technology-dominated areas is often faced with a rapidly moving target and very few planning tools. This paper looks at a new discipline that is emerging and attempts to plot the trend of its emergence. The process of looking at the introduction of a new role for technology as a topic for courses and programs in two countries should help the curriculum planner see the utility of considering a historical perspective when planning for new trends. Competitive intelligence (CI) is a systematic program for gathering and analyzing information about key stakeholders, such as competitors, customers, and suppliers, 
in order to find new opportunities and stay competitive [2]. CI is based on the premise that through analysis of data, companies can predict the probable future actions of these stakeholders. Organizations use the CI process to gather information, to add value to it through analysis, and to report the findings to managers to assist them in making tactical or strategic decisions or satisfy requests for information. CI projects range from obtaining competitive information about competitors or customers to information on recruiting or mergers and acquisitions. The types of information needed for such projects may include financial information, demographics, biographies, economic indicators, news articles, and customer and competitor information. With the vast amount of information that is available on every topic imaginable, it is vital that the knowledge gained from CI activities be managed in a systematic manner. Once the information is secured, it must be analyzed and proper reports must be generated and disseminated to the appropriate individuals within the organization.

CI provides a means of gathering and analyzing information for use in developing global strategies. It is critical to get the right information into the hands of the appropriate people at the time they need it to make decisions [3]. Identification of key economic, social, and technological issues that affect the organization, its life cycle stages, and their relevance to each other helps managers allocate attention and resources to them [4]. Organizational adaptation, survival, and competence in the face of discontinuous environmental change require access to timely and accurate information, as well as tools to constantly monitor, analyze and interpret that information [5]. CI is a fundamental, early step in the chain of perceptions and actions that permit an organization to adapt to its environment [6]. CI must be able to uncover and provide information that will allow management to identify and fill gaps in consumer or business demand curves that are unfulfilled by the products and services that are currently available [7].

\section{CI Education Research}

\subsection{The Development of CI}

Facets of competitive intelligence gathering have been a part of business for many years, but Prescott [8] states that the systematic orientation towards CI is a fairly recent phenomenon, citing Ecells and Nehemkis [9]. Other sources point to Porter's [10] work as the foundation of modern CI. However, Underwood [11] maintains that business-related intelligence came into use in the 1960s. [12], [13], [14], and [15] all published intelligence research during this period [16]. The 1980s saw the introduction of formal intelligence gathering functions and in 1986, 
the Society of Competitive Intelligence Professionals (SCIP) was founded. Juhari and Stephens [17] note that the technology explosion of the 1990s probably stimulated the notion of CI being something new or revolutionary. The emergence of the Internet and online databases offered an almost overwhelming supply of information.

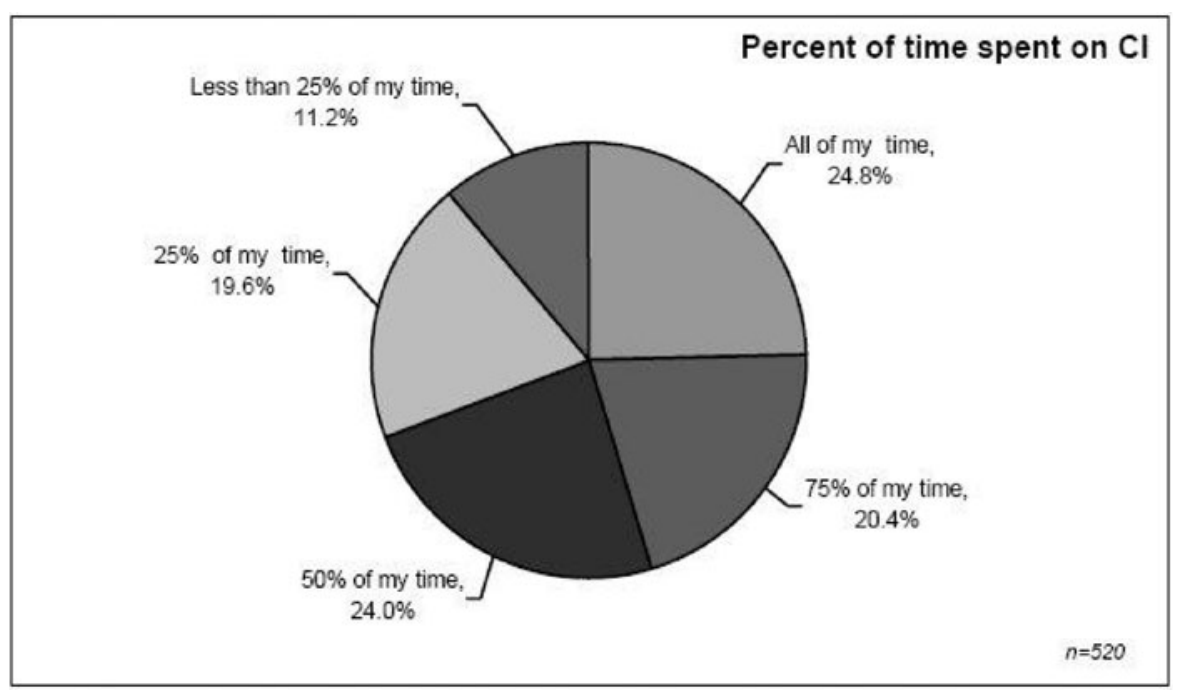

Figure 1 Time spent on CI (from [18])

\subsection{CI in Industry}

It is possible for issues in education to be self-sustaining and independent despite having no real use. Sometimes an issue will be seen as demonstrating some underlying principle that is not yet used in industry. CI is not one of those issues and much evidence can be found of its use. The Competitive Intelligence Institute [18] conducted a survey of over 500 practitioners in 2005 and 2006 and found "Awareness is high and CI visibility has increased in many organizations. Most CI practitioners create exposure to senior management through distribution of their deliverables. They present an excellent opportunity for CI practitioners to demonstrate the value competitive intelligence provides to the organization." This survey showed that CI was mostly a part time activity, but that many practitioners spend much of their time in CI dedicated activities (Figure 1). 
This same survey [18] showed that a wide range of activities in business are supported by CI (see figure 2). We can see, from the existence of the group supporting $\mathrm{CI}$ and the way in which practitioners can identify their $\mathrm{CI}$ activities, that $\mathrm{CI}$ is a part of the industrial landscape.

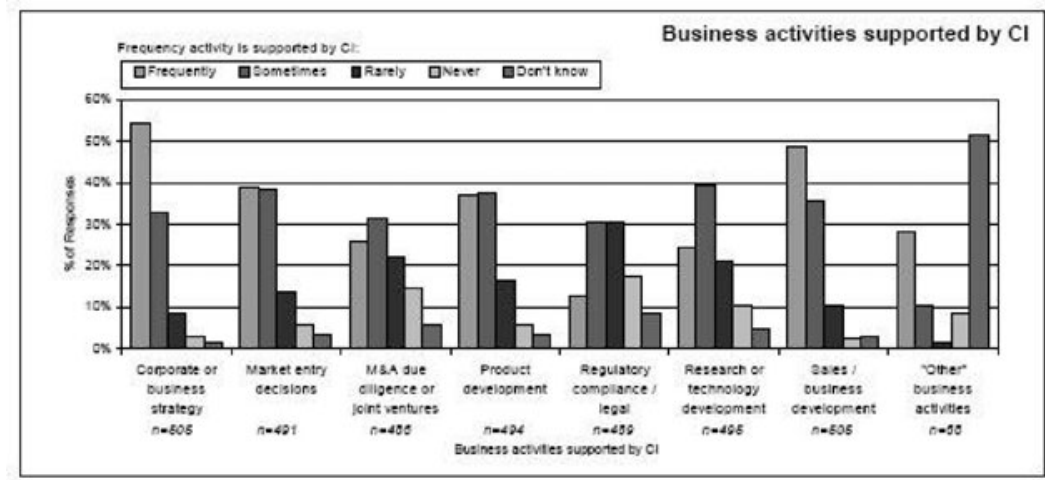

Figure 2 Business activities supported by CI (from [18])

\subsection{CI and Education}

CI education research can take a variety of paths. While some authors focus on what topics are critical to a CI education or the best fit for a CI program, others take different approaches. Some authors focus on the best teaching approaches to use when teaching CI courses. Others prefer to describe what their university has done with their particular CI program. Still others view CI from the context of library science.

\subsection{Overviews of $C I$}

A good starting point for an analysis of CI education research is McGonagle's [19] bibliography of publications that deal with university education and professional training. Prescott [20] presents an informal sampling of CI programs across the globe. Davis, Kohun, and Woratschek [21] also present a table of U.S. Universities and Colleges with offerings in $\mathrm{CL} / \mathrm{BI}$, breaking them down by those that have a degree program, those that offer a professional certificate, and those that offer courses only. 


\subsection{The Dispersion of CI Into Schools}

Merritt [22] laments that most educational institutions have not incorporated CI into their academic programs. He points out that many teach only business research techniques that follow time-insensitive methodologies, ignoring current business requirements. He speculates that a major obstacle to the development of CI courses is a combination of inexperienced instructors and limited teaching materials. He then prescribes a course of action that involves developing suitable instructional materials, training faculty members, and making career placement centers aware of intelligence internships and entry-level CI positions. Fleisher [23] agrees that formal educational offerings in $\mathrm{CI}$ have been constrained by a variety of factors including a dearth of CI offerings at the post-secondary level, confusion about the proper placement of CI studies, and a lack of an agreed upon body of knowledge, core texts, and case studies.

Prescott [8] offers a different perspective. He observes that while business schools may not be teaching dedicated CI courses, most universities offer a wide range of courses that include CI content. With that as a basis, he contends that most schools are already positioned to offer business majors in CI. He ponders that the barrier to implementing a CI major is political rather than economic. Fleisher [23] reflects that educational offerings will likely grow slowly and that prospective and current CI practitioners may have to fall back on formal and selfdirected learning opportunities.

\subsection{Where Does CI Fit In?}

Calof [2] discusses the best fit for a CI course or program using SCIP's CI skills checklist as a yardstick. He stresses the importance of the integration of multiple techniques to understand how the firm should react to various situations. He complains that few schools of business teach interview methodology, revealing his unfamiliarity with the course content of many systems analysis and design courses in information systems programs. He then points out that most universities that offer CI include it in with strategy (his recommendation), although some include it in IS or marketing. He concludes that three approaches should be considered if a school is serious about CI: integration into existing courses, an intelligence capstone course, or a dedicated intelligence program.

Fleisher [23] notes several key trends that are discernible in CI education. They include integration with other disciplines and areas, horizontal education in which knowledgeable industry participants are trained about CI, the increasingly global emphasis of $\mathrm{CI}$ and its need to address global competition and competitors, and the fact that CI education now addresses technology in terms of both content 
and process. He points out that "it would be difficult to teach CI without discussing the importance of database management and structure, secondary data acquisition formats and processes, network formats, enterprise information systems integration, information security, and communication protocols." Miller [24] also stresses integration with other disciplines. He points out that a comprehensive curriculum includes strategy development, market research, primary research methods, statistics, information sources, and interviewing and communication techniques. These topics are drawn from multiple disciplines, including information science, business administration, statistics, communication, and journalism. The intricate relationships between CI and other academic disciplines were also a key theme at the SCIP/Drexel CI Academic Conference [25].

\subsection{What Should Be in a CI Program?}

Miller [24] points out that completing coursework is insufficient preparation for a career as an intelligence professional, especially since many professionals may find the trait-coursework-experience-mentoring sequence inappropriate for their training needs. SCIP/Drexel (2001) discussed the skill sets that CI managers look for in new recruits, such as forecasting, cultural analysis, and experience with analytical techniques. Teaching priorities include such things as the need for MBA capstone courses, forecasting, and training MBAs to be consumers of CI. Miller [26] states that "[a]n effective CI educational program must emphasize practical techniques and approaches for conducting CI rather than nebulous academic theories."

Some studies take a more narrow focus than general issues that impact $\mathrm{CI}$ education. Several reflect on the best teaching approaches to use when teaching CI courses. Blenkhorn and Fleisher [27] look at different teaching approaches that are best suited to the diverse groups that might be encountered in an academic setting, including undergraduates, MBAs, and executives. They conclude by specifying a set of goals that would facilitate teaching CI to the diverse groups, one of which is achieving consensus among $\mathrm{CI}$ educators about the scope of $\mathrm{CI}$ and what it entails. Hulnick [28] describes his experiences in developing a CI course for liberal arts students. Kinsinger [29] discusses how to better prepare MBA students to make better use of CI resources when they join (or rejoin) the workforce. The author first complains that MBA programs do not prepare students to understand the drivers to critical thinking: how they learn, think, and decide. He further generalizes that most MBA teaching is done in off-the-shelf formats. He then states that future executives must be trained to maximize the value that they receive from $\mathrm{CI}$ tools by learning to (1) understand the premium ingredients of a 
quality intelligence product, (2) assess the density and reach of the information source base and the features of the analytical frameworks and methodologies, and (3) understand the necessary logic flow between raw information and insight, and the conclusions and recommendations derived from them.

Some papers present what their university has done with their particular CI program. Davis, Kohun, and Woratschek [21] outline the conception, development, and implementation of the Master of Science in Competitive Intelligence Systems degree at Robert Morris University. They then compare their curriculum to three other universities that offer a graduate degree in CI: American Military University, Dominican University, and Simmons College. Although the RMU curriculum most closely resembles that of Simmons College, it has a stronger foundation in Information Systems. Miller [26] discusses the SCIP curriculum models, a resource that no longer seems to be available, and then describes the Competitive Intelligence Center at Simmons College and provides a summary of the program's course offerings. Prescott [8] examines the curriculum of the Katz Graduate School of Business, comparing the course offerings to the skills required for each component of the intelligence cycle.

\subsection{CI in Library and Knowledge Management Settings}

MacGillivray [30] discusses how her university chose to harness the interrelationships and mutual competencies of CI and KM. She asserts that "looking at the common ground and mutually supportive natures of CI and KM is more beneficial than carving out separate territories", contrary to McGonacle's [31] position that CI and KM have "almost nothing in common." The degree plan that is described is a graduate degree in $\mathrm{KM}$ with a CI component. Finally, Larrat [32] examines the Atelis Competitive Intelligence (CI) educational program. When developing the program they decided to focus on the synergies between intelligence, CI, and knowledge management. They also formed an alliance between the business school, research centers, consultants, and various business organizations. They discuss the required coursework, and then elaborate on a realworld practical group work section designed to provide hands-on training. They conclude that it is by applying techniques in the field that students achieve full awareness of the contribution of a CI approach.

Skills similar to those required of a CI professional are taught in library science or information science programs. Trimberger [33] contends that information and library science schools have been teaching CI-type courses, skills, and techniques for years. The paper goes on to consider how CI skills are taught to information and library science schools and applied by the information professional. In the process of making connections between disparate pieces of 
data, the information professional creates the CI product, a synthesis of that data. That CI product is the information that can be used to gain an advantage in the marketplace. Papik [34] draws parallels between CI educational requirements and those of library science. Davis [35] maintains that in their current form library science degrees are not adequate for prospective CI professionals. She notes that the skills learned in MLS/MLIS degree programs are not sufficient to equip individuals for careers in CI. Instead, training requires basic knowledge of business terminology and some industry knowledge. Further, formal business training and even an MBA are advisable, and therefore more and more library schools are incorporating business courses into their MLS programs to help graduates break into fields such as CI. Shelfer [36] identifies three primary multidisciplinary knowledge domains that contribute to $\mathrm{CI}$ : business, information management, and information science. She then goes on to describe the contributions made by each. Both Shelfer [36] and Shelfer and Goodrum [37] describe the various CI-related degrees offered by Drexel.

\section{Current State of CI in Academia: U.S. and Australia}

The next step in examining CI education is to identify the types of academic offerings currently available at institutions of higher education.

\subsection{U.S. Programs}

Table 1 lists U.S. schools that have been identified as offering courses or programs with a CI component. In the first column are the six schools that offer full degree programs at either the undergraduate or the graduate level. The second column shows the eleven schools that offer professional certification in CI. Three of these offer full degrees as well. The last column lists the sixteen schools that offer only a course (or courses) identified as having CI content. Again, these courses are offered at both the undergraduate and the graduate level. The schools in the first two columns of Table 1 offer formal programs and certificates, and therefore can be used to determine representative course offerings or sequences. The schools that offer only individual CI courses cannot be used in such an analysis and as a consequence only the first two columns will be considered.

A comparison of degree programs and certificate programs reveals that the major difference is that the certificate programs offer more CI-focused content than a traditional academic degree program. This is not unexpected since those seeking a certificate are generally professionals requiring a specialized program that restricts itself to core knowledge about a field such as CI. Degree programs 
normally require students to take a wide range of courses in addition to their specialization, and may therefore incorporate everything from liberal arts to business foundations. In addition, CI programs themselves will vary based on where the program resides. For example, if the $\mathrm{CI}$ degree program resides in the college of business the program places more emphasis on the role of CI in solving business problems, whereas if the CI degree program is associated with an information and library science program there may be an emphasis on finding and cataloging information. Because certificate programs are not representative of typical academic requirements, they will not be considered in our discussion of CI in academia.

Table 1 US CI Education Programs, Certificates, and Courses

\begin{tabular}{|l|l|l|}
\hline Degree Program & Professional Certificate & Courses Only \\
\hline American Military U. & American Military U. & Boston U. \\
Dominican U. & Babson College & Brigham Young U. \\
Johns Hopkins U. & Dominican U. & CalTech \\
Mercyhurst College & Drexel U. & Champlain College \\
Robert Morris U. & Marist College & Harvard U. \\
Simmons College & Notre Dame College & Hawaii Pacific U. \\
& Simmons College & Idaho State U. \\
& Trinity College & Indiana U. \\
& U. of Pennsylvania & Kent State U. \\
& U. of Tennessee & Rutgers \\
& U. of Washington & Thunderbird \\
& & UCLA \\
& & U. of Central Missouri \\
& & U. of Hartford \\
& & U. of Pittsburg \\
& & U. of Texas at Austin \\
\hline
\end{tabular}

An examination of degree titles from the six schools in column one shows a variance across these offerings and shows how few "true" CI programs there are. Table 2 shows that only two of the six are actual master's degrees, three are degree concentrations, and the last is a master's degree in strategic intelligence rather than competitive intelligence. This indicates that the discipline is still in its nascent stages with regard to academia and as such, academia appears not to be meeting the needs of industry. 
Table 2 CI Program Variance

\begin{tabular}{|l|}
\hline Master's Degrees in Competitive Intelligence \\
\hline Robert Morris University \\
Department of Computer and Information Systems \\
Master of Science in Competitive Intelligence Systems \\
Simmons University \\
Graduate School of Library and Information Science \\
Master of Science in Competitive Intelligence \\
\hline Degree Concentrations in Competitive Intelligence \\
\hline American Military University \\
Master of Arts in Intelligence Studies \\
Concentration in Competitive Intelligence \\
Dominican University \\
Brennan School of Business \\
Master of Science in Knowledge Management \\
Concentration in Information Science \\
Johns Hopkins University \\
Carey Business School \\
Master of Business Administration \\
Concentration in Competitive Intelligence \\
\hline Degrees Specializing in Strategic Intelligence \\
\hline Mercyhurst College \\
Institute for Intelligence Studies \\
Master of Science in Applied Intelligence \\
\hline
\end{tabular}

The next step is to examine the required courses in the six-degree programs. Table 3 shows little commonality across the degree programs. Although some of this may be attributed to the above issue regarding where the degree program is housed, there may be other reasons for the lack of a consistent set of courses. On the technical side CI programs offer courses in Database Management, Data Mining and Warehousing, Information Systems Analysis and Design, Informatics, Knowledge Management, and Metadata under a wide variety of titles. On the strategic side CI programs offer a variety of courses with a more managerial basis, such as Strategic Intelligence, Interagency Operations, Competitive Intelligence, Legal and Ethical Issues in Management, Industrial Espionage, Intelligence Theories and Applications, Managing Strategic Intelligence Analysis, Leadership and Organizational Behavior, Introduction to the Intelligence Function, and Organizational and Legal Issues in Technology. There may be some overlap in course content depending on how they are structured. 
Table 3 CI Course Offerings in Graduate Programs

\begin{tabular}{|c|c|c|c|c|c|}
\hline $\begin{array}{c}\text { Robert Morris } \\
\text { University }\end{array}$ & $\begin{array}{l}\text { Simmons } \\
\text { College }\end{array}$ & $\begin{array}{c}\text { American } \\
\text { Military } \\
\text { University }\end{array}$ & $\begin{array}{l}\text { Dominican } \\
\text { University }\end{array}$ & $\begin{array}{c}\text { Johns } \\
\text { Hopkins } \\
\text { University }\end{array}$ & $\begin{array}{c}\text { Mercyhurst } \\
\text { College }\end{array}$ \\
\hline $\begin{array}{c}\text { DS System } \\
\text { Analysis \& } \\
\text { Design }\end{array}$ & $\begin{array}{l}\text { Intro to the } \\
\text { Intelligence } \\
\text { Function }\end{array}$ & $\begin{array}{l}\text { Research } \\
\text { Methods in } \\
\text { Intelligence } \\
\text { Studies }\end{array}$ & $\begin{array}{l}\text { Knowledge } \\
\text { Management }\end{array}$ & $\begin{array}{l}\text { Org. \& Legal } \\
\text { Issues in } \\
\text { Technology }\end{array}$ & $\begin{array}{l}\text { Intelligence } \\
\text { Theories \& } \\
\text { Applications }\end{array}$ \\
\hline $\begin{array}{c}\text { Database } \\
\text { Management } \\
\text { Systems }\end{array}$ & $\begin{array}{c}\text { Basic } \\
\text { Analytical } \\
\text { Tools \& } \\
\text { Techniques } \\
\end{array}$ & $\begin{array}{c}\text { Strategic } \\
\text { Intelligence }\end{array}$ & $\begin{array}{l}\text { Org. Analysis } \\
\text { \& Design }\end{array}$ & $\begin{array}{l}\text { Competitive } \\
\text { Intelligence }\end{array}$ & $\begin{array}{c}\text { Topics In } \\
\text { Intelligence }\end{array}$ \\
\hline $\begin{array}{c}\text { Cyberlaw \& E- } \\
\text { Commerce }\end{array}$ & $\begin{array}{c}\text { Conducting CI } \\
\text { Legally }\end{array}$ & Collection & $\begin{array}{c}\text { Management } \\
\text { Information } \\
\text { Systems }\end{array}$ & $\begin{array}{c}\text { Data Mining \& } \\
\text { Discovery } \\
\text { Informatics }\end{array}$ & $\begin{array}{c}\text { Strategic } \\
\text { Business } \\
\text { Intelligence }\end{array}$ \\
\hline $\begin{array}{l}\text { Computer } \\
\text { Network } \\
\text { Security }\end{array}$ & $\begin{array}{c}\text { Conducting CI } \\
\text { Ethically }\end{array}$ & $\begin{array}{l}\text { Analytic } \\
\text { Methods }\end{array}$ & $\begin{array}{c}\text { Organization of } \\
\text { Knowledge }\end{array}$ & $\begin{array}{c}\text { Knowledge } \\
\text { Management } \\
\text { Systems }\end{array}$ & $\begin{array}{c}\text { Managing } \\
\text { Strategic } \\
\text { Intelligence } \\
\text { Analysis }\end{array}$ \\
\hline CI Systems & \begin{tabular}{|c} 
Business Info. \\
Sources \& \\
Services \\
\end{tabular} & $\begin{array}{l}\text { Interagency } \\
\text { Operations }\end{array}$ & $\begin{array}{l}\text { Information } \\
\text { Policy }\end{array}$ & & $\begin{array}{l}\text { Intelligence } \\
\text { Commun. }\end{array}$ \\
\hline Data Mining & & $\begin{array}{l}\text { Competitive } \\
\text { Intelligence }\end{array}$ & $\begin{array}{c}\text { Org. of } \\
\text { Knowledge }\end{array}$ & & $\begin{array}{l}\text { Leadership \& } \\
\text { Org. Behavior }\end{array}$ \\
\hline \multirow[t]{3}{*}{$\begin{array}{c}\text { Data } \\
\text { Warehousing }\end{array}$} & & $\begin{array}{l}\text { Legal/Ethical } \\
\text { Issues in Mgmt }\end{array}$ & $\begin{array}{c}\text { Database } \\
\text { Management }\end{array}$ & & $\begin{array}{c}\text { Comparative } \\
\text { History of } \\
\text { Intelligence }\end{array}$ \\
\hline & & $\begin{array}{l}\text { Industrial } \\
\text { Espionage }\end{array}$ & $\begin{array}{c}\text { Info Systems } \\
\text { Analysis \& } \\
\text { Design }\end{array}$ & & \\
\hline & & & $\begin{array}{c}\text { CI for Mgmt. } \\
\text { Decision } \\
\text { Making } \\
\end{array}$ & & \\
\hline
\end{tabular}

\subsection{Australian Programs}

Table 4 lists Australian schools that have been identified as offering courses or programs with a CI component. We were unable to locate any Australian universities that offer a degree program or certificate in CI. The last column lists the eight schools that offer only a course (or courses) identified as having CI 
content. Again, these courses may be offered at the undergraduate and/or graduate level. Because the schools that offer only individual CI courses cannot be used in an analysis of representative program content, it is difficult to draw any conclusions about $\mathrm{CI}$ educational offerings in Australia, other than the fact that CI education is not yet considered adequately significant to merit a specialized degree.

Table 4 Australian CI Education Programs, Certificates, and Courses

\begin{tabular}{|l|l|l|}
\hline Degree Program & Professional Certificate & Courses Only \\
\hline \multirow{5}{*}{} & & Curtin U. of Technology \\
& & Macquarie U. \\
& Monash U. \\
& RMIT U. \\
& Swinburne U. of Technology \\
& U. of South Australia \\
& U. of Technology Sydney \\
& & U. of Western Sydney \\
\hline
\end{tabular}

\section{Future Research}

Future research will attempt to establish essential components of CI graduate education, as well as a set of IS courses that best complements a CI program. Additional research will consider the parallel between the development of CI and computer science (CS) programs. Most CS programs were originally founded in either Mathematics or Engineering departments, and many CI programs have their genesis in Information and Library Science programs or in a college of business. In the case of CS, the program was highly influenced by its host discipline, and it will be useful to see if the same holds true of CI programs.

One possible solution to the problem of slow infiltration of CI programs, one that will be elaborated on in a future paper, is the development of multiple CI tracks. These tracks, one with a technical emphasis and one with a managerial emphasis, will be designed with minimal overlap in order to complement each other. The availability of tracks will allow students to select that program that best fits their interests and skills. It will also allow the program to be developed and implemented in increments rather than all at once. A model curriculum will be proposed and made available so that it can be adopted by other schools, thus making more feasible somewhat faster growth of $\mathrm{CI}$ in academia. 


\section{Conclusion}

The literature review establishes that over the last ten years there has been much discussion about the need for a cohesive CI educational program in academia. The examination of the offerings currently available clearly indicates that the need still exists even though some schools now offer degrees or certificates. Many more schools restrict their CI offerings to a single course or a few courses. These courses can, however, serve as a starting point for more detailed programs and help to indicate what will and will not work. Further, their very existence enhances the visibility of $\mathrm{CI}$ with both students and recruiters.

When viewing the deployment of CI courses in terms of the ERP Education Deployment Maturity Model [1], it seems that CI can be categorized as Stage 2 (Adaptive) or Stage 3 (Developing). In the adaptive stage curriculum from others is adapted to the environment of the school, and some integration across courses within disciplines is evident. In the Developing stage curriculum is developed within the school and is specific to courses within the school's environment. This stage is also categorized by integration across disciplines, which is not yet evident.

It is clear from the analysis of existing degree programs that CI educational programs, whether in the US or Australia, are still in their nascent stages. The presence of individual courses in Australia with the complete lack of full degrees or certificate programs shows that $\mathrm{CI}$ is in an earlier stage of evolution in this otherwise developed educational environment. Before they reach full maturity a developed curriculum, as the one described in the future research discussion, must be made repeatable across multiple school environments, and eventually shared with other schools. Finally, that curriculum must be extended to in-depth processes that cross functional silos. It will require time and effort before this is possible for competitive intelligence, but industry need for CI workers may eventually spur greater academic efforts.

\section{References}

1. Antonucci, Y.L., et al., Enterprise systems education: where are we? Where are we going? Journal of Information Systems Education, 2004. 15(3): p. 227-234.

2. Calof, J.L., Teaching CI: Opportunities and needs. Competitive Intelligence Magazine, 1999. 2(4): p. 318-324.

3. Petrash, G., Managing knowledge assets for value., in Knowledge-Based Leadership Conference. 1996, Linkage Inc: Boston.

4. McCann, J. and L. Gomez-Mejia, Going "online" in the environmental scanning process. IEEE Transactions on Engineering Management, 1992. 39(4): p. 394-399.

5. Malhotra, Y., Deciphering the knowledge management hype. Journal for Quality \& Participation, 1998. 21(4): p. 58-60.

6. Hambrick, D.C., Specialization of environmental scanning activities among upper level executives. Journal of Management Studies, 1981. 18(3): p. 299-320. 
7. Johnson, A., Decisions, decisions; Competitive intelligence for predictive decision support and market risk management. KM World, 2005. 14(10): p. 8-11.

8. Prescott, J.E., The evolution of competitive intelligence: Designing a process for action. The Journal of the Association of Proposal Management Professionals, 1999 1(1): p. 37-52.

9. Ecells, R. and P. Nehemkis, Corporate intelligence and espionage: A blueprint for executive decision making. . 1984, New York NY: Macmillan.

10. Porter, M.E., Competitive strategy: Techniques for analyzing industries and competitors. 1980, New York NY: The Free Press.

11. Underwood, J., Competitive intelligence. 2002, Oxford: Capstone Publishing.

12. McGovern, W.M., Strategic intelligence and the shape of tomorrow. 1961, Seattle, WA: Vashon Island Books.

13. Green, R.M., Business intelligence and espionage. 1966, Homewood, IL: Dow Jones-Irwin.

14. Aguilar, F.J., Scanning the Business Environment. 1967, New York NY: Macmillan.

15. Kelley, W.T., Marketing Intelligence: The Management of Marketing Information. 1968, London: Staples Press.

16. Kent, S. On the origins of competitive intelligence. Kent's Imperative, November 30. 2007 [cited 11-1-2007]; Available from: http://kentsimperative.blogspot.com/2007_11_01_archive.html.

17. Juhari, A.S. and D. Stephens, Tracing the origins of competitive intelligence throughout history. Journal of Competitive Intelligence and Management, 2006. 3(4): p. 61-82.

18. Fehringer, D., B. Hohhof, and T. Johnson, State of the Art: Competitive Intelligence. 2006, Competitive Intelligence Institute.

19. McGonagle, J.J., Bibliography: Education in competitive intelligence. Competitive Intelligence Magazine, 2003. 6(4): p. 50.

20. Prescott, J.E., Debunking the "academic abstinence" myth of CI. Competitive Intelligence Magazine 1999. 2(4): p. 22-27.

21. Davis, G.A., F.G. Kohun, and C.R. Woratschek, Curriculum development: Developing a graduate degree program in competitive intelligence. Issues in Information Systems, 2005. VI(1): p. 318-324.

22. Merritt, C., Competitive Intelligence and the Higher Education Dilemma. Competitive Intelligence Magazine, 1999. 2(4): p. 19-21.

23. Fleisher, C.S., Competitive intelligence education: competencies, sources, and trends. Information Management Journal, 2004. 38(2): p. 56-63.

24. Miller, J.P., Educational programs for intelligence professionals - The Library in Corporate Intelligence Activities. . Library Trends, 1994. 43(2): p. 253-270.

25. SCIP/Drexel CI Academic Conference, Academics and practitioners: Forging a partnership. Competitive Intelligence Review., 2001. 12(2): p. 32-36.

26. Miller, J., A comprehensive CI curriculum. Competitive Intelligence Magazine, 2003. 6(4): p. 27-30.

27. Blenkhorn, D. and C. Fleisher, Teaching CI to three diverse groups. Competitive Intelligence Magazine, 2003. 6(4): p. 17-20.

28. Hulnick, A.S., Teaching CI in a liberal arts curriculum. Competitive Intelligence Magazine, 2003. 6(4): p. 56-57.

29. Kinsinger, P., Building a better customer: teaching MBAs how to use CI. Competitive Intelligence Magazine, 2003. 6(4): p. 6-11.

30. MacGillivray, A., Knowledge management education at Royal Roads University. Competitive Intelligence Magazine, 2003. 6(4): p. 37-40.

31. McGonagle, J.J., Competitive intelligence is not knowledge management. Competitive Intelligence Magazine, 2006. 9(4): p. 26-27.

32. Larrat, P., Educating or building awareness on Competitive Intelligence?, in Society of Competitive Intelligence Professionals 2006 Annual International Conference \& Exhibition. 2006: Orlando, Florida

33. Trimberger, K.K. Preparing for the CI role: a student's perspective. Information Outlook. 2000 [cited Feb Available from:

http://www.sla.org/content/Shop/Information/infoonline/2000/feb00/trimberg.cfm 
34. Papik, R. Reasons for Competitive Intelligence Topics in Curriculum of Information and Library Schools. in Proceedings Bobcatsss 15th Symposium, Marketing of Information Services. 2007. Prague.

35. Davis, G.A. Competitive intelligence and librarianship. Suite101.com. 2006 13-12-2006 [cited; Available from: http://www.suite101.com/article.cfm/9460/61236.

36. Shelfer, K.M., CI education that advances CI practice. Competitive Intelligence Magazine., 2003. 6(4): p. 31-36.

37. Shelfer, K.M. and A. Goodrum, Competitive Intelligence as an Extension of Library Education. Journal of Education for Library and Information Science., 2000. 41(4): p. 353361. 